\title{
The Output Hypothesis and Its Implications for Language Teaching
}

\author{
Weiwei Sun \\ School of Foreign Languages and Literature, Beijing Normal University, Beijing, China \\ Email: sunweiweienglish@163.com
}

\begin{abstract}
The Output Hypothesis has been examined broadly in terms of its role in second language acquisition since it was first proposed by Swain. This paper introduces the Output Hypothesis with regard to its basic claims, related research both from home and abroad. Literature will be reviewed from two main dimensions: theoretical discussions and research on teaching practice. This paper will also put forward some implications of the Output Hypothesis for language teaching, with the purpose of contributing to further studies and language teaching practice.
\end{abstract}

Keywords: output hypothesis, literature review, language teaching

\section{Introduction}

In the SLA literature, the role of output in language learning process was relatively unexplored at the very beginning (Izumi, 1999, p.46). Input was considered an important factor for language learning and remained a hot-spot of research in the 1980s. Krashen (1985) proposed the Input Hypothesis, claiming that "If input is understood, and there is enough of it, the necessary grammar is automatically provided" (Krashen, 1985, p.2). He argued that the only requirement for L2 acquisition was access to comprehensible L2 input, which is defined as L2 input just beyond learners' current L2 competence. However, such ignorance of output was questioned by Swain who proposed the Output Hypothesis, which claimed that L2 output was necessary for learning, as a driver of full grammar processing and hypothesis-testing (Swain, 1985). This hypothesis arose from Swain's observations of students' learning experience in Canadian immersion program. The immersion learners were exposed to French-medium instruction for many years, through which their listening and reading ability achieved nearly the same level with the native speakers, but their productive ability lagged behind. They failed to become very accurate in their grammar even after many years in these programs, something which Swain attributed to the missing opportunities of output for the learners (Swain, 1985). She argued that "comprehensible input" was not sufficient for students to fully develop language proficiency, though it was important; "comprehensible output" is also necessary to develop learners' fluency and accuracy in target language. Specifically, she stated that output may serve as "the trigger that forces the learner to pay attention to the means of expression needed in order to successfully convey his or her own intended meaning" (Swain, 1985, p.249).

Since Swain first proposed the Output Hypothesis, there emerged extensive research on output from home and abroad in approximately 24 years. Starting with the basic claims of the Output Hypothesis, this paper will then systematically analyze the research status, present findings and research limitations in terms of the Output Hypothesis. The influence of this hypothesis on teaching theory and practice will also be discussed, aiming to provide implications for language teaching.

\section{Basic Claims of the Output Hypothesis}

Swain (1985) suggested perhaps one function of output may be to drive the learners to form the semantic processing prevalent in the comprehension to the syntactic processing needed in L2 output. She then conducted extensive research to explore the effects of output tasks on language processing.

Swain and Lapkin (1995) chose 18 students from Grade 8 early French immersion class of 21 students as participants and gave them a specific writing task. Each student was asked to think aloud when they were writing. The results showed learners did become aware of gaps of linguistic knowledge and they engaged in thought process which may play a role in second language learning. Therefore, Swain and 
Lapkin (1995) argued that producing a second language triggered the "noticing" of problems, through which three cognitive processes involved in second language learning, that is, generating alternatives, assessing alternatives and applying the resulting knowledge may be resulted in.

Swain (1995) then further extended the scope of his hypothesis and identified the following three functions of output related to accuracy in second language learning: "A 'noticing/triggering' function, or what might be referred to as a consciousness-raising role; A hypothesis-testing function; A metalinguistic function, or what might be referred to as its 'reflective' role" (Swain, 1995, p.128).

She argued that, in producing the target language, learners may encounter linguistic problems leading them to notice what they don't know, or know partially (no. 1); output served as a way of trying out new language forms and structures to stretch their interlanguage to meet the communicative needs (no. 2); and output provided opportunities for learners to reflect on language consciously, allowing them to control and internalize language rules (no. 3). However, in these research, Swain didn't discuss where learners' hypothesis about the target language came from. What's more, these three functions of output don't equal second language learning, so that the specific roles that output plays in L2 learning are still to be examined. Therefore, Swain $(1997,1998,2005)$ carried out research to test the roles of the three functions of output that play in second language learning.

\section{Related Research on the Output Hypothesis}

\subsection{Theoretical Discussions}

Swain's Output Hypothesis served as a turning point in SLA, through which output began to draw researcher's attention. Many empirical studies emerged to examine the Output Hypothesis. Izumi et al. (1999, 2000) examined whether output promoted noticing of linguistic form and whether output resulted in the acquisition of linguistic form by designing two-phase essay writing and reconstructing tasks. It was not confirmed that output promoted noticing of linguistic form; the hypothesis that output resulted in second language acquisition was just partially confirmed. In these two studies, the tasks devised couldn't control he learners' focus of attention with respect to the targeted form, without ensuring that their processing capacity was not overloaded. In addition, Izumi's studies were severely constrained by the small sample size. Following up on Izumi et al.'s (1999, 2000) study, Izumi and Biglow (2000) further investigated learner's cognitive processes triggered by output. They found that output didn't always attract learner's attention to the target grammatical form, but extended opportunities for producing output and relevant input played a crucial role in improving learner's use of target structure.

Some research tried to compare the effects of input and output. Rod Ellis and He Xien (1999) carried out an experimental study of the different effects of pre-modified input, interactionally modified input, and modified output on the comprehension of direction and the acquisition of new vocabulary in a listening-to-do task. It was found that the output modified group outperformed the other two types of input groups both in comprehension and vocabulary acquisition. However, the modified input group and the interaction group didn't show too much difference. The conclusions have been drawn that interaction that provides opportunities for learners to use and negotiate new vocabulary items in dialogically symmetrical discourse seems to create better conditions for incidental vocabulary acquisition than interaction in teacher-controlled exchanges that restrict the kind of inter-mental activity claimed to foster learning. Since this study didn't narrowly distinguish modified input and modified output for the reason that output must be accompanied by input and interaction, so it can not serve as evidence that modified output works better than modified input. The de la Fuente study (2002) had a similar design with learners of L2 Spanish rather than English. In this study, the "output" group of learners also outperformed the rest of students in post-tests with regard to productive vocabulary. The studies quoted both show benefits arising from "pushing" students to produce L2 output, as least as far as vocabulary is concerned. Later, further studies provided supporting evidence for the impact of modified output on the learning of question forms and simple past tense (McDonough, 2005; MacDonough \& Mackey, 2006; Mackey, 2007).

However, Krashen (1998) questioned the Output Hypothesis by posing four difficulties of comprehensible output. He argued that: first, comprehensible output is rare to promote linguistic competence; secondly, high levels of linguistic hypothesis are possible; thirdly, no evidence can show that 
comprehensible output leads to language acquisition; finally, learners feel uncomfortable when forced to output.

After over a decades of research into Swain's Output Hypothesis, there is still a lack of data showing that learner output has any effect on second language learning (Shehadeh, 2002). Therefore, he proposed two sets of research directions in order to move this field forward: the first set relates to modified output and includes examining the direction toward which modifications are made, the specific type of linguistic modifications and the frequency of modified output on L2 learning; "the second set relates to the function of output in L2 learning as a triggering process and includes output as a tool for metalinguistic talk, for noticing and focusing learners' attention on subsequent input" (Shehadeh, 2002, p. 612).

\subsection{Research on Teaching Practice}

Based on the Canadian immersion program, Swain carried out a series of research to test the three functions of the Output Hypothesis. Swain experimented with tasks which encouraged students to engage in collaborative dialogues and found that the tasks where students were asked to write something together tended to elicit collaborative dialogues, which were a source of language learning and promoted the realization of three functions of the Output Hypothesis (Swain, 1997, 1999, 2001, 2005). She also found that it was more effective to focus on forms in rich meaningful contexts than just focusing on meaning in language learning process (Swain, 1996).

With regard to three functions of the output, Nunan worked on task-based teaching that "involving learners in comprehending, manipulating, producing or interacting in the target language while their attention is focused on mobilizing their grammatical knowledge in order to express meaning" (Nunan, 2004 , p.4). He found that the quality of learner output was influenced by the types of tasks, and "pushed" output can be generated by tasks with high cognitive demand and high frequency of negotiation of meaning (Nunan, 2004, cited by Li Ping).

\section{Research on the Output Hypothesis in China}

\subsection{Theoretical Discussions}

It was not until 2000 when Chinese researchers began to pay attention to the Output Hypothesis (Li, 2006). Many Chinese researchers explored under what circumstance output can play a role in second language learning by combining other theories. Li Hong (2002) argued that learners need to have sufficient cognitive resources before they are able to pay attention to both the forms and meanings of their output by analyzing an empirical study carried out by Takashima and Ellis in 1999, which studied the effect of pushed output on learners' acquisition of past tense. Wang Ying (2005) illuminated the psycholinguistic mechanisms by which output promotes second language learning under the framework of Levelt's speech production model. She argued that producing output includes the processing of grammatical encoding for checking the matching of communicative intention and the output, and not all output tasks can trigger the output mechanism which will facilitate second language learning. Therefore, she proposed that learners should be provided meaningful context in language learning in order to obtain form-meaning connections. This study corresponds with Nunan's claim that the high-quality output is generated by the the tasks with high cognitive demand and frequent negotiation of meaning. Song and Dai (2009) found learners can effectively form their hypothesis of the target rule when input enhancement is incorporated into production activities, based on the observations of senior high students' learning in syntactic rules. Some researchers also argued that input and output are both important and they are interdependent so that the quality of both input and output should be stressed in language teaching (You, 1997, 2001; Nie, 2002;Zhong, 2010). However, these studies didn't address the problem that how to allocate the amount of input and output in class order to most effectively promote language teaching.

\subsection{Research on Teaching Practice}

Inspired by the Output Hypothesis, Chinese researchers began to explore how to utilize it to facilitate domestic teaching practice, particularly in speaking and writing. 
Wang Sudan (2001) researched that it was paucity of output in class that has resulted learners' lack of fluency. It was also found that output played an important role in cultivating learners' language sensibility (Wang, 2003). Li Hong (2012) adopted a poster carousel task to examine the role of retelling that played in accuracy, fluency and complexity of learner's interlanguage. 12 college students were required to retell a passage for 5 times, and each sentence they said would be recorded and analyzed. The results showed that the output task retelling improved learners' fluency and accuracy, which served as an evidence for output's facilitative role in second language learning. However, the study was limited by its small size of sample. With the rapid development of multimedia technology, some researchers also explored how to apply it to facilitate language teaching. For example, based on the Output Hypothesis, Shendan and Lu Guojun (2019) took the UNIPUS college English autonomous learning platform as a carrier, and studied the influence of the output module of the platform on the English vocabulary acquisition of students in applied undergraduate colleges, which demonstrated the facilitative role of the output module of autonomous learning platform in promoting vocabulary learning.

\section{$5 \quad$ Implications for Language Teaching}

\subsection{Design Activities that Encourage Students to Produce Output Collaboratively}

In comprehension, students can pass them off as having understood, but in output, students are pushed to process language deeply (Swain, 1995). Teachers should change the comprehension-focused, teachercentered teaching mode and bear in mind that students are the agents of the whole teaching and learning. Activities that involve collaboration and encourage output should be provided for students to use and negotiate new vocabulary items, for example, encouraging students to complete a writing task in a group.

\subsection{Pay Attention to the Difficulty of Tasks in Class}

It is necessary for the task not to place heavy cognitive demands on the learners as they engage in output activities in order for output to lead to final intake (Izumi et al., 1999). If students are preoccupied with generating or organizing their ideas in a difficult task, they may fail to pay much attention to the grammatical aspects of the target language and recognize their problems, which is not beneficial to develop their accuracy in producing output. Therefore, when teachers aim to help learners focus on a specific grammatical form of the input and then produce output, they need to consider ways to adequately control learners' focus by devising appropriate tasks.

\subsection{Provide Feedback for Learners}

Teachers' feedback, such as clarification requests and repetition of learner utterances, performs an indirect role in L2 development and promote learner reformulations and production of modified output (McDough \& Mackey, 2005). Therefore, teachers are supposed to pay attention to students' errors, and can adopt some strategies, like clarification or recast, to help learners notice their problems. The teachers can also ask students to talk about their own conscious reflection on language use in pairs as part of class activities to get peer feedback.

\section{Conclusion}

This paper has introduced foreign and domestic research on the Output Hypothesis, from which it can be seen that no research can confirm that output leads to language acquisition, but provides evidence that output exerts influence on L2 learning at least as far as some aspects are concerned. In China, there is still in-depth and systematic research into output to be expected. What's more, both input and output should be emphasized in Chinese context, and instructors are supposed to put implications of the Output Hypothesis into teaching practice in order to promote learners' language ability. 


\section{References}

1. Ellis, R., \& He, X. (1999). The roles of modified input and output in the incidental acquisition of word meanings. Studies in Second Language Acquisition, 21(2), 285-301.

2. Fang, L. l. (2004). The application of the length approach in college English teaching. Foreign Language World, (3), 40-45.

3. Hong, L. (2012). An experimental study of output and retelling in second language acquisition. Education Research Monthly, (10), 108-110.

4. Izumi, S. (1999). Promoting noticing and SLA: An empirical study of the effects of output and input enhancement on ESL relativization (Unpublished Doctoral dissertation). Georgetown University, Washington, DC.

5. Izumi, S. \& M. Bigelow, M. Fujiw ara, \& S. Fearnow. (1999). Testing the output hypothesis:effects of output on noticing and second lan-guage acquisition. Studies in Second Language Acquisition, 21, 421-452.

6. Izumi, S., \& Bigelow, M. (2000). Does output promote noticing and second language acquisition?. TESOL Quarterly, 34(2), 239-278.

7. Krashen, S. (1985). The Input Hypothesis:Issues and Implications. Harlow: Longman.

8. Krashen, S. (1998). Comprehensible output?. System, 26(2), 175-182.

9. la Fuente, D., \& José, M. (2002). Negotiation and oral acquisition of L2 vocabulary. Studies in Second Language Acquisition, 24(1), 81-112.

10. Li, H. (2002). The cognitive foundations of the Output Hypothesis. Foreign Languages and Their Teaching, (02), $10-12$.

11. Li, P. (2006). Review of the research on the Output Hypothesis. Foreign Languages and Their Teaching, (07), 6064.

12. Lv, L. S. \& Cai, L. P. (2004). Two hypotheses and English writing. Journal of Guangzhou University (Social Science Edition), (07), 48-50.

13. Ma, L. (2017). The application of recitation-input model in writing teaching practice. Language Planning, (32), 8-9.

14. Mackey, A. (2006). Feedback, noticing and instructed second language learning. Applied Linguistics, 27(3), 405430.

15. Mackey, A. (2007). Conversational interaction in second language acquisition: A series of empirical studies. Oxford, England: Oxford University Press.

16. McDonough, K. (2005). Identifying the impact of negative feedback and learners' responses on esl question development. Studies in Second Language Acquisition, 27(1), 79-103.

17. Nie, Q. P. (2002). The input and output of language and foreign language teaching. Journal of Shandong Normal University (Social Science Edition), (04), 123-125.

18. Nunan, D. (2004). Task-based language teaching. Cambridge, England: Cambridge University Press.

19. Shehadeh, A. (2002). Comprehensible output, from occurrence to acquisition: An agenda for acquisitional research. Language Learning, 52(3), 597-647.

20. Shen, D. \& Lu, G, J. (2019). Research on the effect of "output" based on UNIPUS autonomous learning platform on students' English vocabulary acquisition in applied undergraduate colleges. Journal of Jishou University (Social Science Edition), 40(1), 170-177.

21. Song, X. P., \& Dai, W. D. (2009). A study on input enhancement, output and noticing. Foreign Languages and Their Teaching, (10), 5-9.

22. Swain, M.(1985). Communicative competence: some roles of comprehen-sible input and comprehensible output in its development. Rrowley, M: New bury House.

23. Swain, M. (1993). The output hypothesis:Just speaking and writing aren' t enough. The Canadian Modern Language Review, (50), 158-164.

24. Swain, M. (1998). Focus on form through conscious reflection. Cambridge:Cambridge University Press.

25. Swain, M. (2005). The output hypothesis: theory and research. Mahwah, NJ:Lawrence Erlbaum.

26. Swain, M., \& Lapkin, S. (1995). Problems in output and the cognitive processes they generate: A step towards second language learning. Applied Linguistics, 16(3), 371-391.

27. Swain, M. (1997). The output hypothesis, focus on form and second language learning. Hong Kong: University of Hong Kong. 
28. Swain, M. (1999). Integrating language and content teaching through collaborative Tasks. In W.a.Renandya \& C.S. Ward (Eds.), Language teaching: New insights for the language teacher (pp. 125-147). Singapore: Regional Language Center.

29. Swain, M. (2001). Integrating Language and Content Teaching Through Collaborative Tasks. Canadian Modern Language Review, 58(1), 44-63.

30. Swain, M.(2005). The output hypothesis:theory and research. Mahwah, NJ: Lawrence Erlbaum.

31. Swain, M., \& Yang, L. X. (2008). Output hypothesis: Its history and its future. Foreign Language Teaching and Research (bimonthly), 40(1), 45-54.

32. Wang, C. M. (2005a). The Length Approach to Foreign Language Learning. Foreign Languages in China, (01), 45-49.

33. Wang, S. D. (2001). Input and output: The analysis of non-fluency in English class conversation. Journal of Hengyang Normal University (Social Science Edition), (1), 122-124.

34. Wang, Y. (2005). The psycholinguistics foundation of the Output Hypothesis. Foreign Language Education, (04), $18-22$.

35. You, Q. D. (1997). An analysis of "input" and "output". Foreign Language World, (04), 50-53.

36. You, Q. D. (2001). The emphasis of input and output in language application ability. Foreign Language World, (06), 40-43.

37. Zhong, L. \& Wang, T, F. (2008). The influence of the length approach on English writing ability factors-A research report of the length approach in English writing teaching practice. Humanities 8 Social Sciences Journal of Hainan University, (02), 230-236.

38. Zhong, M. (2010). Organic combination of "input" and "output" to promote students' effective learning. Journal of Southwest Minzu University (Humanities and Social Science), 31(1), 37-40. 